\title{
Evaluation of Operating Public Service Performance in Fulfillment Community Expectation in Jakarta
}

\author{
Yuli Harwani \\ Mercu Buana University; yuliharwani@yahoo.com \\ Hesti Maheswari \\ Mercu Buana University; hesti.maheswari@gmail.com
}

Doi:10.5901/mjss.2015.v6n5s5p258

\begin{abstract}
Complaints communities in developing countries, especially Indonesia to the public service is still very high. Perceived imbalances such as in: obscurity time; costs and service delivery; discrimination in services based on the friends relationship, family, political affiliation, ethnic, and even religious; long chain of bureaucracy and increasingly bribery cultured and extortion. This condition is a signal for the government to seek strategic solutions to improve public services. This study aimed to evaluate the operating performance of public services closest to the public, namely the Village, using: quality function deployment at the first and second room to find the community expected and gap analysis, importance performance analysis matrix to determine the attributes of service operations are a top priority for improved, low priority, redundant, and to be preserved. This study successfully mapped 36 public expectations to public services. From all these expectations, it was not one that meets the community expectations, although it did not show high gap. There are 2 indicators in top priority, 3 indicators should be reduced, and 6 indicators should be preserved. On the other hand, mapping the public response to the internet-based administration, showed the public unpreparedness. The majority of respondents stated more comfortable and feel definitely served if the process is directly carried out at the village office and met with officials. The length of the queues and the possibility of intervention or extortion, despite the fact that is a problem for society, but the certainty of completion of service are more important.
\end{abstract}

Keywords: public service, fulfillment public expectation, importance performance analysis

\section{Introduction}

Countries around the world is currently facing pressure from various parties to improve the quality of public services and increase active participation in providing information to the public and demanded to work more affective (Erick, 2011; Suprawoto, 2005). Breakthrough e-government or electronic-based government increasingly important role for all decision makers. Traditional goverment which is identical to the paper-based administration should begin to be abandoned. Traditional transformation into electronic goverment goverment (e-government) became one of public policy issues are hotly discussed today, which aims to reduce barriers or divergence and mal-administration in the implementation of public services as a basic social rights of the people.

Some survey results from international surveys show that the institutions of public services in Indonesia is still the worst in Asia. People's desire has always been considered unrealistic. Especially for public service requirement by financial transactions, such as the maintenance of supporting data regarding land certificate. To take care of making this letter public intentionally made difficult, so impressed it can not be taken care of itself and then ask employees generous nature to help in the hope of reward is not small. Conditions such as these if left longer will give broad impact on social life especially in the economic life of society.

Complaints of various imbalances in the service process as found by the Center for Population Studies UGM (2003), namely: 1) obscurity of time, cost and method of service; 2) was the presence of discrimination in services based on friendly relations, political affiliation, ethnic, and even religious; 3) the length of the chain of bureaucracy, dan and increasingly bribery culture and extortion; 4) Service orientation is not fair; 5) service culture that developed in the direction of power cultural; 6) principle of service is not based on trust, but distrust, while the procedure is applied to control the behavior and not to facilitate; and 7) authority to serve distributed in many bureaucratic unit.

The above conditions forced the government to seek strategic solutions to improve public services. Therefore, it 
needs to do and become the goal of this study is to assess the condition of public services in Indonesia, to evaluate patterns and the performance of services in an effort to improve the quality of service that the local government is closest to the people, village.

\section{Literature Review}

When studied in depth, several factors seem new in the repertoire of public services in Indonesia, such as: community empowerment principle, the system of competition in service provision, oriented on the outcome and not the output only, and the right to earn income from the organizers of public services. These principles should be studied more deeply in order to know the benefits, and then be operated proportionally. To develop a form of public service oriented to the customer satisfaction, the government (PAN decree No. 63/2003) has formulated 15 (fifteen) indicators, namely: simplicity, reliability, workers responsibility, proficiency, Approach to customers, hospitality, openness, Communication between officers and the community, credibility, Clarity and certainty, safety, Understand the customer, reliability of physical facilities, efficience, and economical.

Fifteenth principles of public service is actually enough to make an ideal service model. The application of the principles of these services is dependent upon the delivery of the service bureaucracy. Fifteenth principle will be applied to all or just some of the principles of course depends on the type, nature and pattern of services heldConsideration should also be done is the situation and condition of the people in the place where the public service is.

The concept of public service reform in the book 'Reinventing Government' (Osborne and Gaebler, 1992), are: streering rather than rowing, empower communities to solve their own problems rahter than merely deliver service, promote and encourage competiton rahter than monoplies, be driven by mission rather than rules, result oriented by funding outcomes rather than outputs, meet the needs of the customer rather than of the bureaucracy, concentrate on earning money rhater than just spending it, invenst in preventing problems rathet than curing crises, decentralize authority rather than build hierarchy, and solve problem by influencing market forces rather than treating public programs.

Various forms of mal-administration that is often encountered in Indonesia (www.wikipedia.com) is: delay; incorrect action or failure to take any action; failure to follow procedures or the law; Failure to provide information; Inadequate record-keeping; Failure to investigat; Failure to reply; Misleading or inaccurate statement; Inadequate liaison; Inadequate consultation; and Broken promises.

Definition of mal-administration by Hartono in the investigation guide book for the Indonesian Ombudsman is unnatural behavior (including delay in the delivery of services), disrespectful and less concerned about the problems that befall a person by the actions of abuse of power, including the use of arbitrary power or the power that is used for actions that are not reasonable, unfair, intimidating or discriminatory, and should not be based entirely or partly on the provisions of enactment law or fact, unreasonable, or not based on unreasonable action, Unjust, oppressive, improper and discriminatory (Hartono, 2003). In the book "Getting to know the Indonesian Ombudsman"Masthuri (2005) classify shapes and types of maladministration into six groups, as follows: punctuality, alignments that give rise to a sense of injustice and discrimination, Violations of the laws and regulations, authority competence or provisions that impact on the quality of services provided public officials to the community, the arrogance of a public official, and active corruption.

According to Forman, e-government include the interaction between government and citizens (G2C-government to citizens), government business enterprises (G2B-government-to-business), and the interaction between government (G2G-inter-agency relationship). According to e-government is the use of digital technologies to transform government activities aimed at improving the effectiveness and efficiency of service delivery. This means that the delivery of services through digital technology can provide the level of efficiency in terms of time, cost, and power and effectiveness of government work better (Forman, 2005). According Holle (2011), until today there are no standards in the use of egovernment and there must be those who start to make the rules.

\section{Research Method}

To assess the condition of public services, at an early stage mapping community expectations to public services by holding a group discussion forum (FGD) in 56 villages in Jakarta. Withdrawal sample technique used is the convenience sampling technique (Cochran, 2006). After that, analysis the public services performance by using the house of quality (HOQ) chart in a quality function deployment (QFD) model at the first and the second rooms (Bergquist and Abeysekera, 1996; Vairaktarakis, 1999; Benner et all., 2003; Heizer and Rander, 2012)) and by using a matrix of importance performance analysis (IPA) (Gasperz, 2011) will be found of service attributes that should be preserved because its performance has been good, which should be repaired because the service performance has not been satisfying, which 
should be reduced due to excessive service, and that does not need improvement because although not in accordance with the expectations of society, but not a concern of society.

\section{Data Analysis and Results}

\subsection{Expectations and Public Perception of the Public Service Village}

Respondents in the study are mapped by gender and age. Researchers predict that the differences in gender and age of the respondents have different expectations and perceptions of the public services provided in the village.

The majority of survey respondents are male with nearly twice the number of female respondents. This means that for the affairs of public services such as creating a national identity card (KTP), Family Card (KK), and other public administration at the village level are taken care of by the majority of men. The majority of the reasons women or mothers do not dare to take care of themselves in the village are: lazy, do not understand the process, and fear large costs even though they know these services are free of charge. Men are also worried about his wife will be subject to extortion by the employees of the village because of their ignorance on the process.

Table 1. Respondent Gender and Age by District

\begin{tabular}{|c|c|c|c|c|c|c|c|c|}
\hline \multirow{2}{*}{ No } & \multirow{2}{*}{ Sub-district } & \multicolumn{5}{|c|}{ Age } & \multicolumn{2}{|c|}{ Gender } \\
\hline & & $17-29$ & $30-40$ & $41-50$ & $51-60$ & $60<$ & Man & Female \\
\hline 1 & Cengkareng & 8 & 2 & 14 & 4 & 2 & 18 & 12 \\
\hline 2 & Grogol Petamburan & 10 & 16 & 4 & 4 & 1 & 20 & 15 \\
\hline 3 & Kalideres & 11 & 4 & 5 & 4 & 1 & 23 & 12 \\
\hline 4 & Kebon Jeruk & 15 & 13 & 5 & 1 & 1 & 25 & 10 \\
\hline 5 & Kembangan & 14 & 10 & 3 & 3 & 0 & 23 & 7 \\
\hline 6 & Palmerah & 5 & 13 & 9 & 3 & 0 & 17 & 3 \\
\hline 7 & Taman Sas' & 1 & 13 & 20 & 5 & 1 & 20 & 20 \\
\hline \multirow[t]{2}{*}{8} & Tambora & 7 & 14 & 17 & 5 & 2 & 26 & 19 \\
\hline & Sum & 71 & 85 & 77 & 29 & 8 & 172 & 98 \\
\hline
\end{tabular}

Source: Data processed researchers

This finding also explains that the public service system in village is still hidden and people did not find complete information about the flow of the service. Actually, it can easily find the flow of a service process as displayed on the walls of the village. This process is also commonly found in internet blogs. However, in addition to the people of Indonesia are still very minimal to information via the Internet because they extremely rare interact with the Internetso they become very unfamiliar with the service process. Culture of society in the search for and read information is also very lacking. Concerns point is actually the people think the information that was displayed on the wall is not in accordance with the process in the field so they do not need to read it. If it is the same, the process is made seemed to very difficult and takes a long time, so it needs additional services to finish it.

The majority of people who need services in villages are 30-40 years is 85 people. Another very interesting findings are a few people in between the ages of 17-50 years in the respondents of this study was not actually need the service in the village, rather those who sell services to take care of a service in the village for others (pander).

This happens because of the age between 17-50 years old are in school or work, so that eventually they pay others to attenuate. Of course, costs to be incurred by the society not least. From interviews during deployment questionnaire, found people who complained of the high cost of making the family card and national identity card, which reached up to IDR 700,000, - if processed through these informal services. The government must be sensitive to this complaint and immediately made a breakthrough in the processing in the village on-line by Internet 24 hours, every time and every where, especially after people finished work or school.

The next step in this research is to find what is really expected by society to public services in villages. We distribute open questionnaires to the general public in the area of Jakarta and immediately asked what their expectations of public services in villages on various things without limitations. From this open questionnaire we find hope the majority of respondents to services in the village, namely: quickly and without extortion. If government set the cost of, write clearly that the services cost and how much it is. But if not costly, an employee must not make into a long service process so they were in desperate need of a quick service process is completed, forced to issue a number of costs to speed up the 
process. Even some of the respondents revealed that the village unscrupulous employees without hesitation offer a number of costs if you want taken care of quickly.

To develop a form of public service oriented to customer satisfaction, the government has formulated 15 indicators which are then used as the basis of researchers in making the questionnaire once the researchers want to figure out whether all these indicators may indicate the public's satisfaction to public services. These indicators entered to the first room in the chart house of quality as public needs. Indicators of societal expectations are:

1. The procedure is easy, inexpensive, fast, and smooth, marked by a procedure that is not convoluted.

2. Service performance is the accuracy of services, meticulous in recording the data and punctual

3. Services in accordance with the order of time and contact the people if there is something that is needed

4. Skilled officers and have the knowledge needed

5. Ease of people to contact with officers, either directly or via telephone

6. Friendly, patient, caring and friendship between the people and officers

7. Openness to the the procedure requirements, completion time and cost if there is

8. Communication with the language understood by the public

9. Credibility of service officer

10. Clarity and certainty regarding the procedure, the details of the cost of services and the manner of payment, and the completion of the service timetable.

11. Physical and financial safety

12. The officer gave personal attention

13. Clarity officer's identity

14. Efficient service processes

15. Determination of a reasonable service charge

\subsection{Public Satisfaction of The Village Public Service Overview}

The second step in this research is to get an overview of community satisfaction with services provided by officials in the village by analyzing the gap between expectation and performance. Negative gap indicates the public service in the village has not been satisfactory and vice versa showed positive gap has been satisfaction.

Analysis of the gap in Table 2 shows all indicators gives a negative result, or in other words the public services provided at the level of villages in Jakarta has not been satisfying. Public services in the village are unsatisfying, are: 1) The procedure is easy, inexpensive, fast, and smooth, marked by a procedure that is not convoluted, very far from expectations $(-0,42) ; 2)$ Service performance is the accuracy of services, meticulous in recording the data and punctual ($0,40)$ actually is needed, However because of services provided free of charge, the officer worked very relaxing and deliberately not provide certainty when service is completed. Even with no precise time they create opportunities to charge fees for people who want to be served quickly; 3 ) Credibility of service personnel $(-0,36)$ at the time of serving and resolve the problem very disappointing. This happened not because of the inability of the officers, but rather the unwillingness of officers to serve well; 4 ) Ease of people to contact village officers, either directly or by phone $(-0,31)$ is the next indicator of community dissatisfaction. People often complain the difficulty of asking the clerk if a service has been completed or not. Society is difficulty getting confirmation of completion of making identity cards or a family card.

Table 2. Public Needs \& Gap Analysis Public Service (Villages) in Jakarta

\begin{tabular}{|c|c|c|c|}
\hline No Public Needs (The First Room of HOQ) & $\mathrm{MCl}$ & MCS & GAP (The 2nd room) \\
\hline $\begin{array}{l}1 \text { The procedure is easy, inexpensive, fast, and smooth, marked by a procedure that is not } \\
\text { convoluted. }\end{array}$ & 3.28 & 2.86 & -0.42 \\
\hline $\begin{array}{l}\text { Service performance is the accuracy of services, meticulous in recording the data and } \\
\text { punctual }\end{array}$ & 3.41 & 3.01 & -0.40 \\
\hline $\begin{array}{l}3 \text { Services in accordance with the order of time and contact the people if there is something } \\
\text { that is needed }\end{array}$ & 3.27 & 2.98 & -0.29 \\
\hline 4 Skilled officers and have the knowledge needed & 3.31 & 3.04 & -0.27 \\
\hline 5 Ease of people to contact with officers, either directly or by phone & 3.03 & 2.72 & -0.31 \\
\hline 6 Friendly, patient, caring and friendship between the people and officers & 3.36 & 3.10 & -0.26 \\
\hline 7 Openness to the the procedure requirements, completion time and cost if there is & 3.27 & 3.05 & -0.22 \\
\hline 8 Communication with the language understood by the public & 3.33 & 3.05 & -0.28 \\
\hline 9 Credibility of service officer & 3.31 & 2.95 & -0.36 \\
\hline
\end{tabular}


10 Clarity and certainty regarding the procedure, the details of the cost of services and the

manner of payment, and the completion of the service timetable.

11 Physical and financial safety

12 The officer gave personal attention

13 Clarity officer's identity

14 Efficient service processes

15 Determination of a reasonable service charge

$\mathrm{MCl}$ : mean publics importance;

MCS : mean publics satisfaction

Source: data processed researchers;

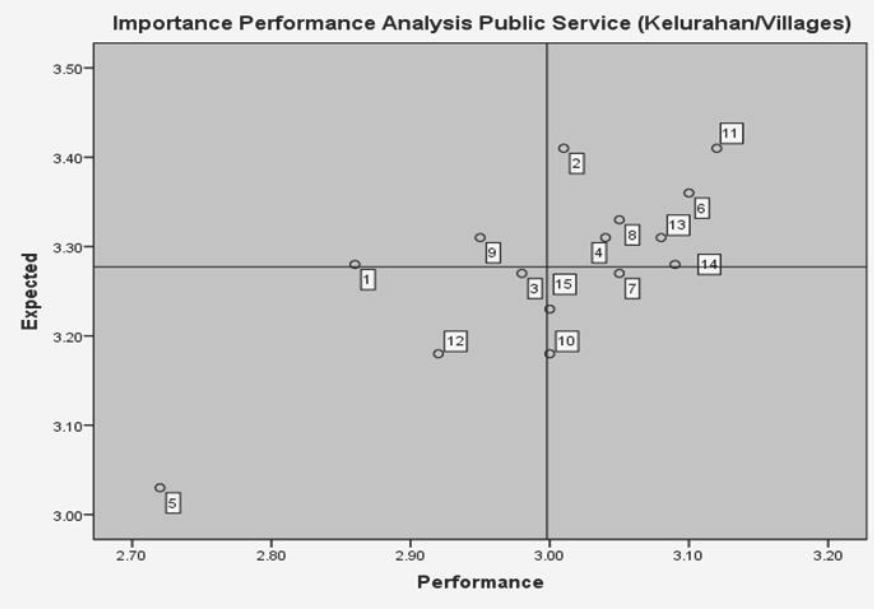

Figure 1. The Service Quality Villages Evaluation

From the figure 1, illustrated clearly that the public is very demanding service procedure easy, inexpensive, fast, and smooth, characterized by procedures that are not straightforward (atribut 1 ) and the credibility of the officers (atribut 9) because both of these attributes in the first quadrant to be a top priority. This also proves that the Local Government should immediately fix both of these attributes. Under the IPA matrix, service attributes that should be maintained by the village because it is in conformity with the expectations of society (quadrant 2, maintain performance), namely: Service performance is the accuracy of services, meticulous in recording the data and punctual (2), Skilled officers and have the knowledge needed (4), Friendly, patient, caring and friendship between the people and officers (6), Communication with the language understood by the public (8), Physical and financial safety (11), Efficient service processes (14), and Clarity officer's identity (13). Service attributes village that low-performance but not a concern for the community (quadrant 3 , low priority) are, The officer gave personal attention (12), Services in accordance with the order of time and contact the people if there is something that is needed (3), dan people ease to contact with officers, either directly or by phone (5).

While the village services which are considered excessive (quadrant 4), is: Openness to the the procedure requirements, completion time and cost if there is (7), Clarity and certainty regarding the procedure, the details of the cost of services and the manner of payment, and the completion of the service timetable (10), and determination of a reasonable service charge (15). Service to the three attributes (quadrant 4) is excessive therefore the village should reduce performance on these attributes and more focus on attributes in quadrant 1.

\subsection{Mapping Community Response to The Internet-based Administration Public Service Alternatives}

In the final stage of this research, will be mapped public response to village services with Internet-based administration system. This is the first step to a benchmark analysis of China that indeed the majority of public services have been online. Here are the results of the mapping community responses to public administration services on-line (by internet): 
Table 3. Community Response Against the Internet-based Administration

\begin{tabular}{lc}
\hline \multicolumn{1}{c}{ Statement } & Number of Responses \\
\hline 1. Making the identity cards and family cards can be accessed via the Internet & 78 \\
Strongly agree & 48 \\
Agree & 62 \\
ordinary & 82 \\
Disagree & \\
Reasons disagree: hard, difficult access to government web, unusual (good care of directly in the village), unfamiliar, unusual use \\
of the internet, technology stutter. \\
\hline 2. Making the identity cards and family cards over the Internet to avoid contact with the clerk, it will reduce extortion, the \\
$\quad$ intervention of the officers, and no queues & 76 \\
Strongly supports & 51 \\
Support & 88 \\
Ordinary & 55 \\
Not support & 148 \\
Reasons not support: not sure the process is right, do not know how, never used the Internet, unusual, stuttering technology. \\
willing to support & 122 \\
not willing to support & \\
The reason is not willing: no time, can not, do not want, wasting time & \\
\hline
\end{tabular}

\section{Source: Data processed researchers}

From the above table reflected the readiness of Indonesian citizens to public services on-line. There are many Indonesian people are not fluent reading, and then they will be difficult if they have to use high technology such as the internet. Actually, government efforts to introduce usage the internet to the public have started since elementary school. Hope that someday people who stutter technology will be less so that e-government will be realized. The government must continue to focus on trying to make people literate in technology, especially the very need to be considered are the inland regions Indonesia.

\section{Conclussion and Managerial Implication}

Gap analysis results indicate that all of services provided in village disappointing, especially on the convoluted procedure, expensive, slowly; lack service performance such as inaccuracy of services, meticulous in recording the data and not punctual; uncredibility of service officer, and dificult to contact the officers either directly or by phone. From importance and performance analysis (IPA), There are two services that entered into the quadrant top priority because of the expectations of society to these services is very high while the low performance, ie on the procedure is easy, inexpensive, fast and smooth, marked by a procedure that is not convoluted and Credibility of service officer. Latest finding from this research is about the unpreparedness of society to internet-based public services.

\section{References}

Forman, Mark, 2005. E-Goverment: Using IT to Transform The Effectiveness and Efficiency of Goverment

Hartono, Sunaryati; Budhi Masthuri, Enni Rochmaeni, Winarso. Panduan Investigasi untuk Ombudsman Indonesia. Diterbitkan atas dukungan The Asia Foundation Indonesia 2003.

Holle, S. Erick, 2011. Pelayanan Publik Melalui Electronic Goverment: Upaya Meminimalisir Praktek Maladministrasi dalam Meningkatkan Public Service, Jurnal Sasi

Indrajit, R.E. 2002. E-Goverment: Strategi Pembangunan dan Pengembangan Sistem Pelayanan Publik Berbasis Teknologi Digital. Penerbit: Andi, Yogyakarta.

LAN dan BPKP. 2000. Akuntabilitas Kinerja dan Good Governance. Jakarta: Lembaga Administrasi Negara.

Masthuri, Budi, 2005. Mengenal Ombudsman Indonesia. Penerbit Pradnya Paramitra, Jakarta

Oshborne, David and Ted Gaebler, 1992. Reinventing Goverment. Reading, MA: A Plume Book.

Pusat Studi Kependudukan UGM, 2003. Karakteristik Ketidakpuasan Masyarakat Terhadap Pelayanan Publik dalam LAN: Penyusunan Standar Pelayanan. Jakarta: Lembaga Administrasi Negara.

Suprawoto, 2005 Pelayanan Publik Melalui E-Goverment (studi tentang pelayanan KTP, e-Procurement dan PSB-Online di Kota Surabaya). Disertasi Universitas Brawijaya, Malang. 